\title{
PUBLIC RELATIONS DAN MASYARAKAT DALAM MEMACU PERTUMBUHAN PARIWISATA
}

\author{
Yuanita Safitri \\ Marketing Communication Department, Faculty of Economics and Communication, BINUS University \\ Jln. K.H. Syahdan No.9, Palmerah, Jakarta Barat 11480 \\ Yuanita.sds@gmail.com
}

\begin{abstract}
Tourism is an important determinant for a region's economic growth-the higher income from tourism, the higher its gross regional domestic product. To be successful in exposing potential tourism sites, a region does not only depend on the beauty of the nature but also how to access the sites, on-site accommodation and the mutual relationship between local government and local community.The fact is many regions have difficulties in developing mutual relationship between local government and local community. It means what most important is how the tourism industry is being managed. One most important aspect of managing the tourism industry is the cooperation and communication between the local community and the government. This article aims to discuss how public relations and the local community work to stimulate tourism growth in a synergy. Using descriptive qualitative method, this article recommends a model of communication strategy-in which the local community serves mainly as the tourism's public relation agents, and also serves as a reference method in evaluating a local government's communication strategies in regional tourism industry.
\end{abstract}

Keywords: public relations, tourism

\begin{abstract}
ABSTRAK
Pariwisata adalah salah satu sektor yang penting bagi petumbuhan suatu daerah. Dengan memaksimalkan potensi pariwisata, akan dapat menaikkan pertumbuhan ekonomi bagi daerah tersebut. Untuk membuat sebuah daerah berhasil pariwisatanya, tidak hanya keindahan alam yang dibutuhkan, tetapi juga akses untuk menuju ke daerah tersebut, akomodasi yang memadai, serta komunikasi yang baik antara masyarakat dan pemerintah daerah. Namun, di lapangan ternyata masih banyak daerah yang masih kesulitan dalam membina komunikasi dan menyamakan pemahaman antara pemerintah daerah dan masyarakat setempat. Artinya yang paling penting adalah bagaimana industry pariwisata dikelola. Artikel ini akan membahas bagaimana public relations dan masyarakat dapat bersinergi untuk memacu pertumbuhan pariwisata suatu daerah.Artikel ilmiah ini dapat menjadi acuan evaluasi bagi daerah tentang strategi komunikasi yang baik, khususnya dalam bidang pariwisata. Metode yang digunakan pada penelitian ini adalah deskriptif kualitatif. Pengambilan data menggunakan teknik observasi, dan studi kepustakaan. Hasil penelitian ini merekomendasikan suatu model strategi komunikasi pariwisata daerah, di mana masyarakat menjadi public relations bagi daerahnya.
\end{abstract}

Kata kunci: public relations, pariwisata 


\section{PENDAHULUAN}

Ketika Anda berkunjung ke sebuah kota dan bertanya kepada penduduk sekitar tentang potensi yang ada di kota tersebut, maka Anda akan merasa kecewa ketika penduduk menjawab bahwa di kota mereka tidak ada tempat pariwisata. Bahkan mungkin Anda tidak mau kembali ke kota tersebut, dan jika ada orang lain yang bertanya kepada Anda tentang kota tersebut, maka Anda akan mengatakan sesuai dengan apa yang Anda ketahui di kota tersebut bahwa di sana tidak ada tempat pariwisata. Namun, lain halnya apabila Anda datang ke suatu daerah dan bertanya kepada penduduk sekitar tentang potensi pariwisata yang ada di kota tersebut, mereka dapat menjelaskan dengan baik tempat pariwisata yang mereka miliki beserta akses untuk menuju ke tempat tersebut. Tentu Anda akan senang untuk melihat potensi pariwisata di kota tersebut. Apalagi jika Anda merasa bahwa apa yang dimiliki kota tersebut menarik, Anda tidak akan segan untuk memberitahukan kepada relasi dan rekan-rekan Anda. Para wisatawan lainnya juga tidak segan untuk kembali berkunjung ke daerah tersebut.

Dataran Tinggi Dieng, Wonosobo, Jawa Tengah terkenal dengan keindahan alam yang masih terjaga, Puncak Sikunir, Candi Arjuna, Telaga Warna, dan lain sebagainya. Satu hal yang menarik dari perjalanan tersebut adalah penduduk sekitar terlihat sangat sadar akan potensi yang ada di daerah mereka. Kepada siapapun yang bertanya, mereka dapat menjelaskan dengan fasih tentang potensi yang mereka miliki, sampai dengan akses untuk menuju ke tempat tersebut. Di sini kita bisa melihat keberhasilan dari pemerintah daerah Wonosobo dalam menjadikan masyarakat sebagai public relations. Masyarakat sudah cukup mengerti akan pentingnya informasi yang jelas tentang suatu daerah kepada para wisatawan.

Keindahan Flores dapat dinikmati dari berbagai media, baik lokal maupun internasional. Keindahan alam Flores sudah tidak diragukan lagi. Banyak sekali foto-foto yang beredar di internet memperlihatkan keindahannya. Bahkan, pemerintah Indonesia dengan program Wonderful Indonesia menjadikan Flores dengan Gunung Kelimutunya sebagai salah satu fokus dari destinasi wisata dalam negeri, selain Pulau Komodo, Raja Ampat, Wakatobi, serta Bromo-Tengger-Semeru, dan Sanur. Namun, yang ironis adalah penduduk sekitar yang tidak mengetahui potensi pariwisata apa yang mereka miliki, sehingga seringkali mereka mengatakan bahwa di Flores tidak ada potensi pariwisata. Jawaban seperti itu tentu mengecewakan wisatawan yang telah meluangkan waktu, tenaga, dan biaya untuk mengunjungi suatu daerah. Karena tidak ingin pulang dengan tangan kosong, ada wisatawan yang berinisiatif untuk bepergian sendiri di sana. Alangkah terkejutnya wisatawan tersebut, ketika dia menemukan beberapa pantai yang sangat indah, masih sepi dan belum tersentuh. Ini membuktikan bahwa apa yang penduduk katakan bahwa tidak ada potensi pariwisata di Flores, mungkin hanya ketidaksadaran akan potensi pariwisata yang mereka miliki. Tentu ini menjadi pekerjaan rumah bagi pemerintah daerah, pada khususnya, dan Kementerian Pariwisata dan Ekonomi Kreatif, pada umumnya. Artikel ini akan membahas lebih jauh tentang bagaimana mensinergikan public relations dan masyarakat dalam upaya untuk memacu pertumbuhan pariwisata di sebuah daerah.

\section{METODE}

Penelitian ini menggunakan metode deskriptif kualitatif. Penelitian deskriptif ditujukan untuk: (1) mengumpulkan informasi aktual secara rinci yang melukiskan gejala yang ada, (2) mengidentifikasikan masalah atau memeriksa kondisi dan praktek-praktek yang berlaku, (3) membuat perbandingan atau evaluasi, (4) menentukan apa yang dilakukan orang lain dalam menghadapi masalah yang sama dan belajar dari pengalaman mereka untuk menetapkan rencana dan keputusan pada waktu yang akan datang (Rakhmat, 2005). Dalam mencari data, peneliti melakukan teknik 
observasi, dan studi kepustakaan, dari buku, jurnal, koran, serta internet. Observasi yang digunakan pada penelitian ini adalah observasi langsung. Di mana peneliti turun langsung ke lapangan, dan melihat secara langsung situasi yang terjadi di lapangan.

Tujuan penelitian ini adalah untuk mendeskripsikan peranan masyarakat sebagai public relations bagi industri pariwisata di daerahnya. Dalam artikel ilmiah ini, juga dipaparkan dengan singkat, dua contoh kasus yang dapat menjadi perbandingan. Diharapkan, penelitian ini dapat menjadi evaluasi bagi daerah tentang strategi komunikasi yang baik, khususnya dalam bidang pariwisata.

\section{HASIL DAN PEMBAHASAN}

Indonesia adalah sebuah negara kepulauan yang memiliki potensi pariwisata yang besar, terutama dalam bidang pariwisata. Jika berbicara tentang Indonesia, kebanyakan orang akan langsung teringat akan keindahan alamnya. Namun sayangnya, hanya daerah-daerah tertentu saja yang sudah memanfaatkan keelokan alam Indonesia ini, Bali contohnya. Bahkan, masyarakat internasional pun banyak yang tidak menyadari bahwa Bali hanyalah bagian kecil dari Indonesia.

Tidak bisa dipungkiri bahwa, untuk menjadi sebuah daerah wisata yang layak dikunjungi, kita tidak bisa hanya fokus kepada keindahan alam saja. Infrastruktur dan akses transportasi yang baik, akomodasi yang memadai, serta keramahan dari masyarakat merupakan faktor yang sangat penting. Keramahan dari masyarakat sekitar, disadari atau tidak, adalah salah satu faktor yang membuat wisatawan merasa nyaman, betah, bahkan ingin kembali lagi ke daerah tersebut. Ketika wisatawan ditanya mengenai pengalaman mereka mengunjungi kota Jogjakarta, sebagian besar wisatawan mengatakan kota tersebut sangat ramah dan keramahan tersebut menimbulkan kenyamanan. Contoh keramahan tersebut adalah kesediaan masyarakat untuk membantu wisatawan ketika mereka tersesat atau kebingungan mencari lokasi sebuah tempat wisata. Masyarakat sekitar mau membantu jika ada wisatawan yang lagi tersesat atau kebingungan. Itu adalah salah satu contoh kecil, di mana ada faktor yang sering tidak disadari ini dapat menjadi penunjang meningkatnya pariwisata di suatu daerah.

Kepuasan pengunjung dapat dilatari oleh kawasan wisata yang informatif, baik dari segi masyarakat maupun fasilitas yang ada di kawasan tersebut. Kawasan wisata yang informatif dapat menjadi trigger bagi pengunjung untuk tahu lebih dalam tentang kawasan tersebut. Hal ini juga bisa menjadi keunggulan yang dapat menghasilkan keuntungan bagi sebuah kawasan wisata.

Sejak diberlakukannya Undang-Undang No 21 Tahun 1999 sebagaimana telah direvisi dengan Undang-Undang No 32 Tahun 2004 tentang Pemerintahan Daerah atau Otonomi Daerah, kini setiap daerah memiliki kewenangan untuk membuat kebijakan terkait dengan pertumbuhan dan kemajuan daerah tersebut. Otonomi daerah membuat daerah berlomba-lomba untuk menjadi yang terdepan di berbagai bidang. Dengan adanya otonomi daerah, seharusnya dapat lebih memudahkan daerah untuk mengembangkan potensi yang dimiliki daerah tersebut, serta memperkenalkannya kepada masyarakat luas. Memang, dibutuhkan kreatifitas, kesadaran, serta peran serta masyarakat sekitar agar keinginan untuk memajukan wisata daerah dapat diwujudkan. Pariwisata daerah, juga dapat menjadi jalan masuk bagi investor, baik lokal maupun asing. Selain itu, pariwisata yang maju juga akan berpengaruh positif dalam memajukan taraf kehidupan masyarakat sekitarnya.

Butler (1980) merumuskan A Hyphothetical Cycle of Area Evolution atau yang dikenal dengan tahapan dalam pembangunan pariwisata, tahapan tersebut dapat dilihat pada gambar berikut: 


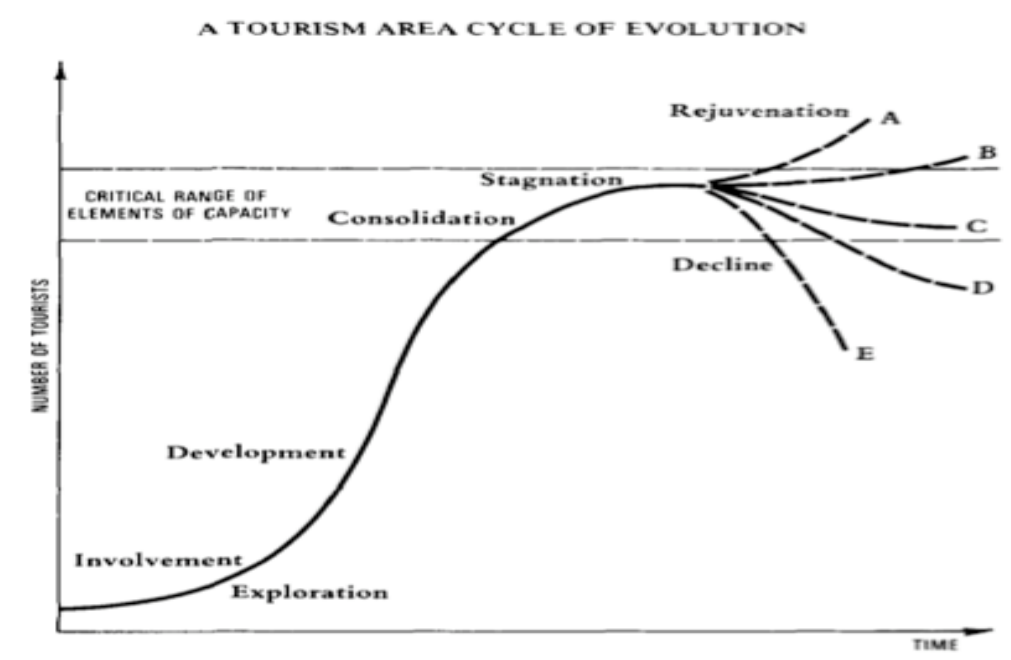

Gambar 1 Hypothetical evolution of a tourist area (Butler, 1980)

\section{Tahap Penemuan (Exploration)}

Potensi pariwisata berada pada tahapan identifikasi dan menunjukkan destinasi memiliki potensi untuk dikembangkan menjadi daya tarik atau destinasi wisata karena didukung oleh daya tarik keindahan alam yang masih alami sebagai wisata alamiah yang sangat asli. Selain itu juga, telah ada kunjungan wisatawan dalam jumlah kecil dan leluasa bertemu dan berkomunikasi serta berinteraksi dengan penduduk lokal. Karakteristik ini cukup untuk dijadikan potensi pengembangan pariwisata.

\section{Tahap Pelibatan (Involvement)}

Pada tahap pelibatan, masyarakat lokal mengambil inisiatif dengan menyediakan berbagai pelayanan jasa untuk para wisatawan. Masyarakat dan pemerintah lokal sudah mulai melakukan sosialiasi atau periklanan dalam skala terbatas, pada musim atau bulan atau hari-hari tertentu misalnya pada liburan sekolah terjadi kunjungan wisatawan dalam jumlah besar, dalam kondisi ini pemerintah lokal mengambil inisiatif untuk membangun infrastruktur pariwisata namun masih dalam skala dan jumlah yang terbatas.

\section{Tahap Pengembangan (Development)}

Pada tahapan ini, telah terjadi kunjungan wisatawan dalam jumlah besar dan pemerintah sudah berani mengundang investor nasional atau internasional untuk menanamkan modal di kawasan wisata yang akan dikembangkan. Organisasi pariwisata mulai terbentuk dan menjalankan fungsinya khususnya fungsi promotif yang dilakukan bersama-sama dengan pemerintah sehingga investor asing mulai tertarik dan memilih destinasi yang ada sebagai tujuan investasinya.

\section{Tahap Konsolidasi (Consolidation)}

Pada tahap ini, sektor pariwisata menunjukkan dominasi dalam struktur ekonomi pada suatu kawasan dan ada kecenderungan dominasi jaringan international semakin kuat memegang peranannya pada kawasan wisata tersebut. Kunjungan wisatawan masih menunjukkan peningkatan yang cukup positif namun telah terjadi persaingan harga diantara perusahaan sejenis pada industri pariwisata pada kawasan tersebut. Peranan pemerintah lokal mulai semakin berkurang sehingga diperlukan konsolidasi untuk melakukan re-organisasional, dan balancing peran dan tugas antara sektor pemerintah dan swasta. 


\section{Tahap Stagnasi (Stagnation)}

Pada tahapan ini, angka kunjungan tertinggi telah tercapai dan beberapa periode menunjukkan angka yang cenderung stagnan. Walaupun angka kunjungan masih relatif tinggi namun destinasi sebenarnya tidak menarik lagi bagi wisatawan. Wisatawan yang masih datang adalah mereka yang termasuk repeater guest atau mereka yang tergolong wisatawan yang loyal dengan berbagai alasan. Program-program promosi dilakukan dengan sangat intensif namun usaha untuk mendatangkan wisatawan atau pelanggan baru sangat sulit terjadi. Pengelolaan destinasi melampaui daya dukung sehingga terjadi hal-hal negatif tentang destinasi seperti kerusakan lingkungan, maraknya tindakan kriminal, persaingan harga yang tidak sehat pada industri pariwisata, dan telah terjadi degradasi budaya masyarakat lokal.

\section{Tahap Penurunan atau Peremajaan (Decline/Rejuvenation)}

Setelah terjadi Stagnasi, ada dua kemungkinan bisa terjadi pada kelangsungan sebuah destinasi. Jika tidak dilakukan usaha-usaha keluar dari tahap stagnasi, besar kemungkinan destinasi ditinggalkan oleh wisatawan dan mereka akan memilih destinasi lainnya yang dianggap lebih menarik. Destinasi hanya dikunjungi oleh wisatawan domestik saja itupun hanya ramai pada akhir pekan dan hari liburan saja. Banyak fasilitas wisata berubah fungsi menjadi fasilitas selain pariwisata. Jika Ingin Melanjutkan pariwisata perlu dilakukan pertimbangan dengan mengubah pemanfaatan destinasi, mencoba menyasar pasar baru, mereposisi atraksi wisata ke bentuk lainnya yang lebih menarik.

\section{Masyarakat sebagai Public Relations Daerah}

Dalam definisi kerja (working definition) oleh International Public Relations Assosiations (IPRA) dinyatakan bahwa ada berbagai definisi yang dikemukakan oleh para ahli Public Relations, yaitu: (1) Public Relations merupakan suatu kegiatan yang bertujuan untuk memperoleh good will, kepercayaan, dan saling pengertian dan citra baik dari masyarakat. (2) Sasaran Public Relations adalah berupaya menciptakan opini public yang baik dan menguntungkan semua pihak. (3) Public Relations merupakan unsur yang cukup penting dalam mendukung manajemen untuk mencapai tujuan yang spesifik dari organisasi atau lembaga. (4) Public Relations adalah usaha untuk menciptakan hubungan yang harmonis antara suatu lembaga atau organisasi dengan pihak masyarakat melalui suatu proses komunikasi timbal balik, hubungan yang harmonis, saling mempercayai, dan menciptakan citra yang positif. (Ruslan, 2008)

Dari definisi di atas dapat dilihat bahwa tujuan utama dari public relations adalah untuk memperoleh Good will, kepercayaan, saling pengertian dan mendapatkan citra (Image) yang baik di mata masyarakat. Pada definisi tersebut disebutkan kata Good will (niat baik) yang memiliki kedekatan arti dengan reputasi. Jika disambungkan dengan pembahasan pariwisata, maka dengan ada niat baik dari sebuah daerah untuk memajukan daerah tersebut dan dengan ada sinergi serta kolaborasi antara pihak pihak yang menjadi stakeholder serta masyarakat setempat, maka hal ini akan membawa kepercayaan baik di mata masyarakat setempat sebagai publik internal, maupun para wisatawan dari luar daerah tersebut, serta para investor sebagai publik eksternal. Kepercayaan ini akan berbuah manis yaitu citra yang baik bagi daerah tersebut. Citra yang baik dalam jangka waktu yang lama akan menumbuhkan reputasi yang baik pula. Jika hal ini terjadi secara terus menerus dan berkesinambungan, maka keuntungan juga akan kembali kepada daerah tersebut. Pariwisata ramai, lapangan pekerjaan meningkat, taraf hidup masyarakat juga semakin naik.

Public Relations (humas) daerah harusnya bisa merangkul masyarakat setempat dalam upaya mengedukasi dan menjadikan masyarakat sebagai public relations daerah tersebut. Partisipasi masyarakat sangat dibutuhkan bagi keberlangsungan pariwisata daerah ini. Masyarakat bisa memiliki profesi apa saja (bukan public relations) tetapi mereka dapat menjalankan fungsi sebagai public relations yang baik bagi daerahnya. 
Ardianto dan Soemirat (2010) mengklasifikasikan publik dalam Public Relations menjadi beberapa kategori yaitu: (1) Publik internal dan publik eksternal: Internal publik yaitu publik yang berada di dalam organisasi/ perusahaan seperti supervisor, karyawan pelaksana, manajer, pemegang saham dan direksi perusahaan. Eksternal publik secara organik tidak berkaitan langsung dengan perusahaan seperti pers, pemerintah, pendidik/ dosen, pelanggan, komunitas dan pemasok. (2) Publik primer, sekunder, dan marginal. Publik primer bisa sangat membantu atau merintangi upaya suatu perusahaan. Publik sekunder adalah publik yang kurang begitu penting dan publik marginal adalah publik yang tidak begitu penting. Contoh, anggota Federal Reserve Board of Governor (Dewan Gubernur Bank Amerika) yang ikut mengatur masalah perbankan, menjadi publik primer untuk sebuah bank yang menunggu rotasi secara teratur, di mana anggota legislatif dan masyarakat menjadi publik sekundernya. (3) Publik tradisional dan publik masa depan. Karyawan dan pelanggan adalah publik tradisional, mahasiswa/pelajar, peneliti, konsumen potensial, dosen, dan pejabat pemerintah (madya) adalah publik masa depan. (4) Proponent, opponent, dan uncommitted. Di antara publik terdapat kelompok yang menentang perusahaan (opponents), yang memihak (proponents) dan ada yang tidak peduli (uncommitted). Perusahaan perlu mengenal publik yang berbeda-beda ini agar dapat dengan jernih melihat permasalahan. (5) Silent majority dan vocal minority: Dilihat dari aktivitas publik dalam mengajukan complaint (keluhan) atau mendukung perusahaan, dapat dibedakan antara yang vokal (aktif) dan yang silent (pasif). Publik penulis di surat kabar umumnya adalah the vocal minority, yaitu aktif menyuarakan pendapatnya, namun jumlahnya tak banyak. Sedangkan mayoritas pembaca adalah pasif sehingga tidak kelihatan suara atau pendapatnya.

Ada beberapa peran utama public relations: (1) sebagai communicator atau penghubung antara organisasi atau lembaga yang diwakili dengan publik. (2) Membina hubungan yang positif dan dan saling menguntungkan dengan publik. (3) Sebagai pendukung fungsi manajemen. (4) Menciptakan citra positif bagi organisasi atau lembaganya.

Sebagai communicator, Public relations seharusnya dapat memberitahukan kepada masyarakat tentang harapan pemerintah daerah tentang daerah tersebut. Jangan sampai pemerintah daerah "asik sendiri" dengan program-programnya, tetapi masyarakat nihil informasi tentang apa yang pemerintah kerjakan, terutama dalam bidang pariwisata. Gap informasi antara pemerintah daerah dan masyarakat akan membawa dampak yang buruk bagi pertumbuhan pariwisata daerah tersebut.

Untuk menjadi communicator yang baik, humas daerah juga harus menjadi listener yang baik terlebih dahulu. Mendengarkan harapan-harapan dari masyarakat tentang potensi wisata daerah tersebut juga dapat menjadi salah satu cara yang baik untuk membangun pariwista daerah tersebut. Tidak hanya mendengarkan harapan dari masyarakat, humas daerah juga harus mampu mendengarkan aspirasi dan keinginan dari para wisatawan. Bagaimana caranya? Di zaman teknologi yang sudah semakin canggih, humas daerah dapat memantau aspirasi wisatawan melalui internet. Humas daerah dapat membuat situs khusus untuk berkomunikasi dengan wisatawan, dan calon-calon wisatawan di manapun mereka berada. Humas daerah juga dapat memanfaatkan media sosial sebagai salah satu sarana berkomunikasi dengan wisatawan dan calon wisatawan.

Dengan mengedukasi masyarakat, akan lebih memudahkan humas daerah dalam menyamakan suara, menjembatani kebingungan-kebingungan publik, terutama publik eksternal. Mengedukasi masyarakat ini bisa dilakukan dengan beberapa cara, antara lain adalah dengan membentuk komunitas komunitas khusus yang fokus utamanya adalah pengembangan wisata daerah. Anggota dari komunitas inilah yang akan berkeliling ke daerah-daerah yang akan dikembangkan menjadi fokus tujuan wisata daerah tersebut dan mengedukasi masyarakat setempat tentang hal-hal yang mungkin ditanyakan oleh para wisatawan, dan bagaimana caranya agar orang-orang yang mengunjungi daerah tersebut menjadi nyaman berada di daerah mereka. Edukasi ini bisa dilakukan dengan mengadakan pelatihan-pelatihan untuk masyarakat di lingkungan RT atau RW mereka atau bisa juga melalui kelurahan atau kecamatan. 
Selain itu PR juga bisa memaksimalkan peran masyarakat sebagai bagian dari riset. Riset merupakan bagian yang tidak terpisahkan dari dunia public relations. Public relations yang berhasil selalu memulai kegiatannya dengan riset dan dari situ data yang konkrit diperoleh. Masyarakat sebagai bagian yang selalu ada di lapangan, mereka yang mengetahui keadaan sebenarnya. Jika humas daerah enggan untuk merangkul masyarakat maka, bagaimana mungkin data yang tepat akan diperoleh?

\section{Public Relations Mix Dalam Penerapan Strategi Komunikasi Pariwisata Daerah}

Dalam dunia marketing, ada konsep yang dikenal dengan marketing mix. Ini adalah perpaduan beberapa macam konsep marketing. Perpaduan beberapa konsep kegiatan juga dikenal dalam dunia public relations, atau biasa yang dikenal dengan istilah Public Relations Mix. Public Relations Mix juga dikenal dengan konsep PENCILS (Ruslan, 2008), yaitu: Publications, Event, News, Community Involvement, Lobbying and Negotiations dan Social Responsibility.

\section{Publications}

Fungsi dan tugas public relations adalah menyebarluaskan informasi yang baik tentang oranisasi atau perusahaan melalui berbagai media. Masyarakat dapat mengambil peranan yang besar dari publications ini. Apabila masyarakat dapat menjamu wisatawan yang datang dengan baik, maka wisatawan tersebut tentu akan merasa senang, dan mereka tidak segan untuk membantu daerah tersebut melalui berbagai cara, seperti misalnya, menceritakan pengalaman mereka berkunjung melalui blog, atau website khusus pariwisata, menyebarkan pengalaman tersebut melalui media sosial, serta menceritakan kepada sanak saudara dan teman-teman mereka. Umumnya, orang akan lebih percaya jika publikasi tersebut bersifat lebih personal dibandingkan hanya melalui iklan biasa.

\section{Event}

Kegiatan yang bertujuan untuk memperkenalkan atau mempopulerkan suatu hal. Sebuah event membutuhkan biaya yang besar, karena meliputi beberapa hal berikut: (1) Sewa lokasi. (2) Honor untuk artis pendukung. (3) Biaya periklanan dan promosi. (4) Biaya pembangunan set tempat. (5) Biaya pengorganisasian (event organizer) (Hardiman, 2006).

Public Relations (Humas) di daerah dapat membuat kegiatan-kegiatan yang menunjang pertumbuhan wisata daerah tersebut dengan mengikutsertakan masyarakat. Apalagi masyarakat Indonesia masih kental dengan konsep gotong royong. Apabila mereka dilibatkan secara aktif dalam kegiatan tersebut, diberitahukan secara terbuka tujuan dari kegiatan tersebut, tentu mereka akan dengan senang hati membantu. Namun, apabila masyarakat tidak pernah diikutsertakan dalam berbagai event public relations, mereka tentu akan merasa tidak dibutuhkan oleh daerahnya sendiri. Kolaborasi antara pemerintah dan masyaraat akan menghasilkan suatu kawasan wisata yang dapat dinikmati oleh semua pihak.

\section{News (menciptakan berita)}

Upaya untuk menciptakan berita melalui press release, news letter, buletin, dll. Di sini masyarakat bisa diajak untuk turut serta menulis tentang daerah tersebut, apa yang menarik dari daerah tersebut, bagaimana cara mencapai daerah tersebut dari berbagai daerah lain. Kemudian, meminta mereka untuk menyebarkan tulisan mereka melalui berbagai sumber, seperti Koran, majalah, dan internet. Jika masyarakat daerah tersebut belum mengerti cara menggunakan internet, pemerintah daerah dapat memfasilitasi untuk mengajarkan kepada mereka bagaimana caranya menggunakan internet dengan bijak. Karena tidak bisa dipungkiri, bahwa internet adalah media baru yang sangat berpengaruh belakangan ini. Pemerintah daerah juga dapat menjadi pendorong masyarakat untuk menggunakan media sosial sebagai sarana edukasi tentang kawasan wisata tersebut. Jika 
menggunakan media sosial humas daerah dapat membuat hash tag (\#) atau tagar resmi terutama khusus untuk kawasan wisata daerah tersebut. Dengan cara ini, masyarakat dapat lebih memiliki sense of belonging kepada daerah mereka. Dari masyarakat untuk masyarakat.

\section{Community Involvement (Keterlibatan Masyarakat)}

Dalam konteks pariwisata, community involvement adalah keterlibatan atau dukungan masyarakat dalam kegiatan pariwisata. Dengan dukungan masyarakat, kegiatan pariwisata akan berjalan semakin baik dan wisatawan menjadi semakin nyaman berkunjung. Hal ini juga akan menghindari terjadinya hal-hal anarkis, seperti pencurian, perampokan, perkosaan, pembunuhan, pemboman, dsb.

\section{Inform or image}

Dalam Kamus Besar Bahasa Indonesia, pengertian citra adalah: (1) kata benda: gambar, rupa, gambaran; (2) Gambaran yang dimiliki orang banyak mengenai pribadi, perusahaan, organisasi atau produk; (3) Kesan mental atau bayangan visual yang ditimbulkan oleh sebuah kata, frase atau kalimat, dan merupakan unsur dasar yang khas dalam karya prosa atau puisi; (4) Data atau informasi dari potret udara untuk bahan evaluasi. Poin nomor dua adalah pengertian citra yang paling dekat dengan konsep Public Relations.

Jefkins (2005) menyebutkan beberapa jenis citra (image). Berikut ini lima jenis citra yang dikemukakan, yakni: (1) Citra bayangan (mirror image). Citra ini melekat pada orang dalam atau anggota-anggota organisasi biasanya adalah pemimpinnya mengenai anggapan pihak luar tentang organisasinya. (2) Citra yang berlaku (current image). Adalah suatu citra atau pandangan yang dianut oleh pihak-pihak luar mengenai suatu organisasi. (3) Citra yang diharapkan (wish image). Adalah suatu citra yang diinginkan oleh pihak manajemen. (4) Citra perusahaan (corporate image). Adalah citra dari suatu organisasi secara keseluruhan, jadi bukan sekedar citra atas produk dan pelayanannya. (5) Citra majemuk (multiple image). Banyaknya jumlah pegawai (individu), cabang, atau perwakilan dari sebuah perusahaan atau organisasi dapat memunculkan suatu citra yang belum tentu sama dengan organisasi atau perusahaan tersebut secara keseluruhan.

Setiap daerah memiliki citra yang ingin dibangun. Dengan memberikan sosialisasi yang berkala dan efektif kepada masyarakat, maka akan ada kesinambungan antara harapan pemerintah daerah dengan pemahaman masyarakat. Tidak hanya memiliki pemahaman yang sama, masyarakat juga diharapkan dapat menjadi “corong” pemerintah daerah dalam setiap kegiatan pariwisata yang dilakukan. Kesamaan makna citra yang akan dibentuk antara pemerintah dan masyarakat ini, tentu akan menjadi poin yang positif bagi kemajuan suatu daerah.

\section{Lobbying and negotiation}

Negosiasi menurut Kamus Besar Bahasa Indonesia adalah: proses tawar menawar dengan jalan berunding untuk memberi atau menerima guna mencapai kesepakatan antara satu pihak dan pihak yang lain dapat berupa kelompok atau organisasi.

Agar dalam berkomunikasi lebih efektif dan mengena sasaran dalam negosiasi harus dilaksanakan dengan melalui beberapa tahap yakni: (1) Fact-finding, mencari/mengumpulkan faktafakta data yang berhubungan dengan kegiatan lawan sebelum melakukan negosiasi. (2) Planning/rencana, sebelum bernegosiasi susun garis besar pesan yang hendak disampaikan. Berdasarkan kerangka topik yang hendak dibicarakan rinci hasil yang diharapkan akan diraih. (3) Penyampaian, lakukan negosiasi/sampaikan pesan dalam bahasa lawan/si penerima. Usahakan gunakan istilah khas yang bisa dipakai oleh lawan negosiasi kita. Pilihlah kata-kata yang mencerminkan citra yang spesifik dan nyata. Hindari timbulnya makna ganda terhadap kata yang 
disampaikan. (4) Umpan balik, negosiator harus menguasai bahasa tubuh pihak lawan. Dengarkan baik-baik reaksi lawan bicara. Amati isyarat prilaku mereka seperti: angkat bahu, geleng-geleng kepala, mencibir, mengaggguk setuju. Umpan balik dapat untuk mengetahui samakah makna yang disampaikan dengan yang ditangkap lawan negosiasi kita. (5) Evaluasi, perlu untuk menilai apakah tujuan negosiasi sudah tercapai, apakah perlu diadakan lagi, atau perlu menggunakan cara-cara untuk mencapai hasil yang lebih baik.

Karena Public relations tidak akan pernah lepas dari publik, baik internal maupun eksternal, tentu kemampuan negosiasi sangatlah dibutuhkan. Dalam berbagai kegiatan public relations, banyak hal yang membutuhkan keahlian negosiasi. Misalnya pada saat pengambilan keputusan, penyelesaian masalah, pengurusan perizinan, dan lain sebagainya.

\section{Social Responsibility}

Definisi Corporate Social Responsibility (CSR) menurut World Business Council on Sustainable Development adalah komitmen dari bisnis/perusahaan untuk berperilaku etis dan berkontribusi terhadap pembangunan ekonomi yang berkelanjutan, seraya meningkatkan kualitas hidup karyawan dan keluarganya, komunitas lokal dan masyarakat luas. Definisi lain, CSR adalah tanggung jawab perusahaan untuk menyesuaikan diri terhadap kebutuhan dan harapan stakeholders sehubungan dengan isu-isu etika, sosial dan lingkungan, di samping ekonomi (Warta Pertamina, 2004).

Aspek tanggung jawab sosial dalam dunia Public Relations adalah isu cukup penting, di mana organisasi tidak hanya memikirkan keuntungan materi bagi lembaga, tetapi juga kepedulian kepada masyarakat. Bentuk kepedulian kepada masyarakat ini bisa dilakukan dengan berbagai macam cara, yang jika berhasil, maka organisasi akan mendapatkan reputasi yang baik. Organisasi yang memiliki reputasi bagus, umumnya akan mendapatkan enam hal berikut: (1) Hubungan yang baik dengan para pemuka masyarakat. (2) Hubungan positif dengan pemerintah setempat. (3) Resiko krisis yang lebih kecil. (4) Rasa kebanggaan dalam organisasi dan di antara khalayak sasaran. (5) saling pengertian antara khalayak sasaran, baik internal maupun eksternal. Dan terakhir, meningkatkan kesetiaan para staf perusahaan (Anggoro, 2002).

\section{Strategi Komunikasi}

Strategi komunikasi adalah perpaduan antara perencanaan (planning) dan manajemen untuk mencapai tujuan tertentu dalam praktik operasionalnya. Para ahli sependapat bahwa, strategi komunikasi yang efektif dapat menghasilkan hal berikut: (1) Bagaimana mengubah sikap (how to change the attitude). (2) Bagaimana mengubah opini (how to change the opinion). (3) Bagaimana mengubah perilaku (how to change behavior) (Ruslan, 2008)

Dengan mengikutsertakan masyarakat sebagai bagian dari public relations daerah, maka sikap acuh masyarakat terhadap daerah sendiri diharapkan bisa berubah. Mereka akan semakin mencintai daerahnya, serta menjaga daerah tersebut. Sense of belonging yang tinggi, juga akan membuat masyarakat memiliki kebanggaan akan daerahnya. Masyarakat yang bangga akan daerahnya, tentu akan menceritakan hal baik kepada para wisatawan, ini menjadi motivasi agar wisatawan kembali datang ke daerah mereka. Dengan hal ini, diharapkan pula wisatawan yang datang menjadi semakin bertambah. Strategi komunikasi pariwisata daerah yang telah dijelaskan di atas dapat dilihat pada model berikut. 


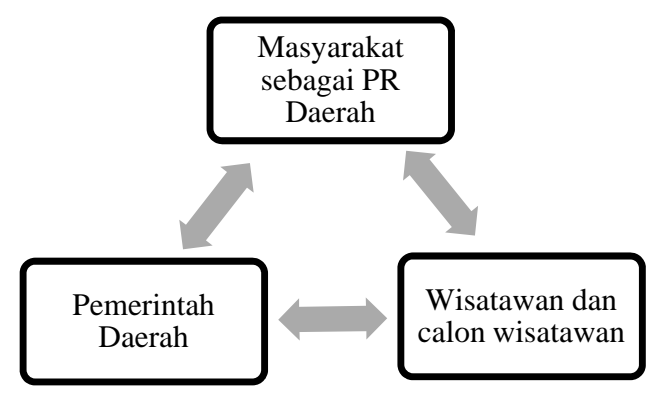

Gambar 2 Strategi Komunikasi Pariwisata Daerah

\section{SIMPULAN}

Menggandeng masyarakat sebagai public relations daerah, merupakan strategi yang sangat dibutuhkan bagi perkembangan kegiatan pariwisata daerah. Hal ini sering didengungkan, namun masih banyak daerah yang sulit mempraktekan. Pemerintah daerah dapat menjadi pendorong masyarakat untuk menjadi public relations bagi daerahnya. Salah satu caranya adalah dengan melakukan sosialisasi kepada masyarakat tentang visi pariwisata serta melibatkan masyarakat dalam berbagai kegiatan public relations. Kunci utamanya adalah komunikasi antara pemerintah daerah (Humas) dan masyarakat setempat, serta kesamaan pemahaman akan citra yang ingin dibangun.

\section{DAFTAR PUSTAKA}

Anggoro, L. (2002). Teori dan Profesi Kehumasan. Serta Aplikasinya di Indonesia. Jakarta: Bumi Aksara

Ardianto, E., Sumirat, S. (2010). Dasar-dasar Public Relations. Bandung: Remaja Rosdakarya

Butler, R. W. (1980). The concept of a tourist area cycle of evolution: implications for management of resources. The Canadian Geographer, 24, 5-12.

Hardiman, I. (2006). 400 Istilah PR, Media dan Periklanan. Jakarta: Gagas Ulung.

Jefkins, F. (2005). Public Relations. Jakarta: Erlangga.

Rakhmat, J. (2005). Metode Penelitian Komunikasi. Bandung: Remaja Rosada Karya.

Ruslan, R. (2008). Kampanye Public Relations. Jakarta: Raja Grafindo Persada.

Warta Pertamina. (2004). CSR sebagai Strategi Bisnis. Diakses 20 Februari 2014 dari http://www.pertamina.com/. 